\title{
New Chromosome Counts in Cousinia (Asteraceae) from Flora of Iran
}

\author{
Firouzeh Bordbar*, Mozhdeh Baqeri and Mansour Mirtadzadini \\ Department of Biology, Faculty of Sciences, Shahid Bahonar University of Kerman, Kerman 76169-14111, Iran
}

Received May 19, 2017; accepted July 10, 2017

\begin{abstract}
Summary In this study, we report the chromosome number on the eight Cousinia species belonging to six sections distributed in south east and north east parts of Iran. Seven of the counts are new to science and one provides confirmation of the previous report. The results of this study are the first reports of the basic chromosome number within sect. Spinuliferae and sect. haussknechtianae. The present study reports $x=12$ for C. lasiolepis from sect. Alpinae which is new for the material originated from flora of Iran. The result of this study also confirmed the previously reported basic chromosome number of $x=13$ which had been supposed to be erroneous for sect. Leiocaules.
\end{abstract}

Key words Cardueae, Cousinia, Iran, Karyology.

Cousinia Cass. is one of the largest genera of Cardueae from Asteraceae. It comprises over 700 species worldwide which is mainly centered in SW and C Asia (Rechinger 1986, Susanna and Garcia-Jacas 2009). Among them, more than 250 species are distributed in Iran, mainly in Elburz and Zagros mountains (Zare et al. 2013).

Chromosome number data are powerful source along taxonomy, pollen morphology and molecular studies to establish natural groups in complex taxa (Soltis 2014). Regarding the complexity within the Arctium-Cousinia group, karyology has provided useful information to understand the karyological evolution and natural classification of this group (Susanna et al. 2003a). Considering the literature (Djavadi 2007, 2012, Djavadi and Attar 2010, Sheidai et al. 2012, Parishani et al. 2014), up to now chromosome number reports are existed for about 120 species of Cousinia belonging to flora of Iran. This number represents only $48 \%$ of the species in Iran. Therefore, this study contributes to provide more and new information of karyology in Cousinia.

Materials and methods

The karyotype analysis was performed on the following taxa: Cousinia pulcherantha Attar \& Mirtadzadini, C. beauverdiana Bornm, C. longifolia Winkl. \& Bornm., C. sicigera Winkl. \& Bornm., C. diezii Rech. f., C. lasiolepis Boiss., C. haussknechtii C. Wink1, and C. cylindracea Boiss. belonging to six sections. Selection of the studied species was done according to herbarium materials, which were deposited in Herbaium Mirtadza-

*Corresponding author, e-mail: bordbar@uk.ac.ir

DOI: $10.1508 /$ cytologia.82.485 dini (MIR). We followed the sectional classification of Rechinger $(1972,1979)$ as the newest classification for Cousinia species.

Mitotic studies were made on metaphase cells of root tips obtained from germinating seeds on wet filter paper in Petri dishes at $25^{\circ} \mathrm{C}$ temperature. Root tips were pretreated for $5 \mathrm{~h}$ in $\alpha$-monobromonaphthalene at $4^{\circ} \mathrm{C}$ and washed and fixed in Carnoy solution $(3: 1$, absolute ethanol:glacial acetic acid) for $24 \mathrm{~h}$. The root tips were hydrolyzed in $1 \mathrm{~N} \mathrm{HCl}$ solution at $60^{\circ} \mathrm{C}$ for about $7 \mathrm{~min}$, washed and stained in aceto-iron hematoxilin for $24 \mathrm{~h}$ at $30^{\circ} \mathrm{C}$ (according to Agayev 1996 with some modifications). The roots were gently squashed in $45 \%$ acetic acid on a slide glass. The clearest mitotic metaphases of 5-10 cells were photographed with an Olympus BH-2 light microscope equipped with camera photomicrograph system. For each species ideograms were obtained using IdeoKar 1.1 (Mirzaghaderi and Marzangi 2015).

\section{Results}

Karyotypes and idiograms of the following examined species are presented in Figs. 1-16.

Cousinia sect. Leiocaules Bunge

Cousinia pulcherantha Attar \& Mirtadzadini

Iran: S., NE of Kerman, Kuhpayeh, Mirtadzadini 2046, $2 n=24$ (Figs. 1 and 9).

This is the first chromosome count for C. pulcherantha. The observation of this study revealed $x=12$ for this species. According to Djavadi and Attar (2010), $x=12$ (majority of reports) and 13 (only in one species) have been reported for Cousinia species belonging to this section. C. pulcherantha is a narrow endemic species restricting to a very small area in south east of Iran. 

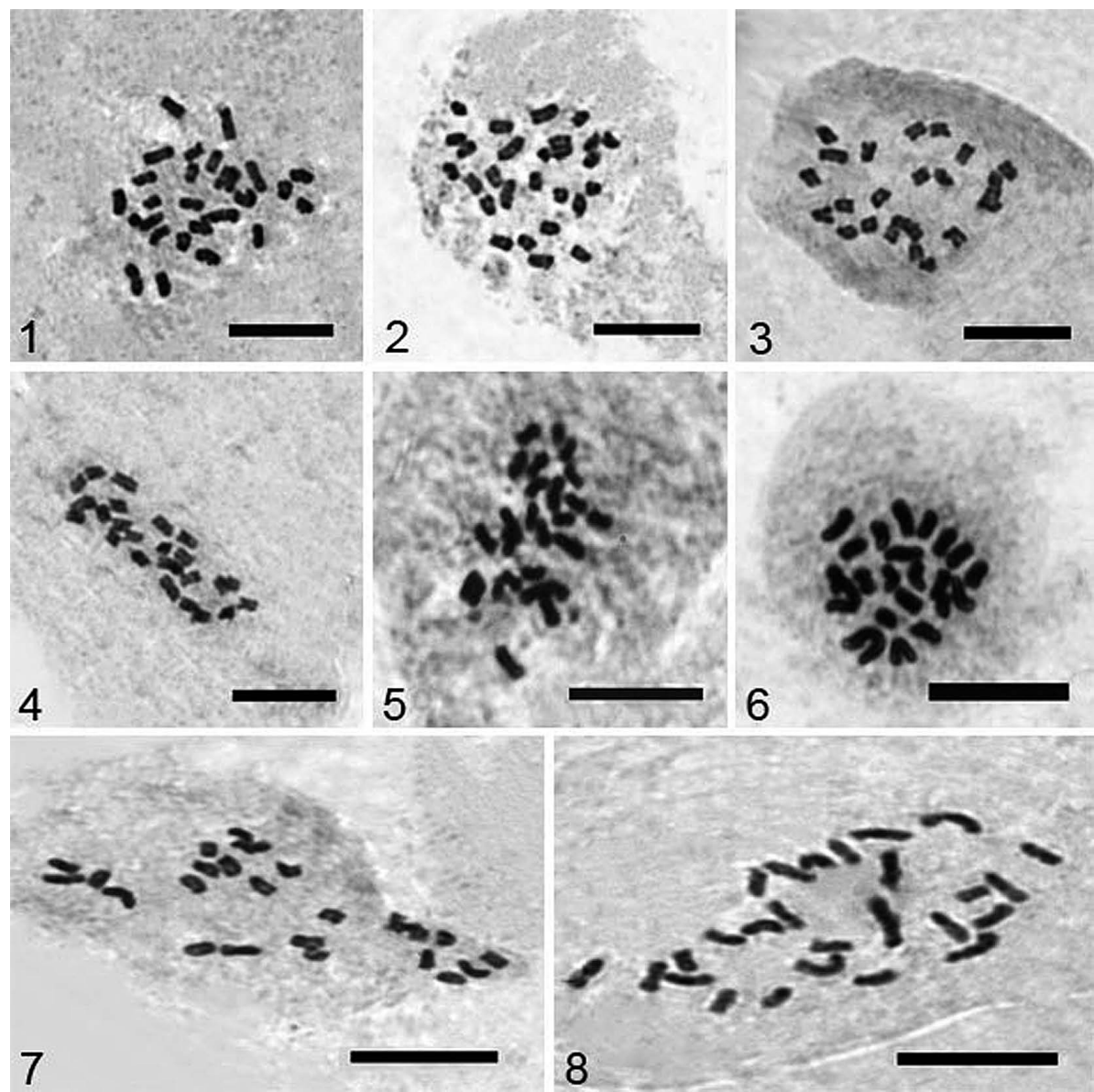

Figs. 1-8. Metaphase chromosomes of Cousinia species. 1. C. pulcherantha, 2. C. beauverdiana, 3. C. longifolia, 4. C. sicigera, 5. C. diezii, 6. C. lasiolepis, 7. C. haussknechtii and 8. C. cylindracea. Scale bar $=10 \mu \mathrm{m}$.
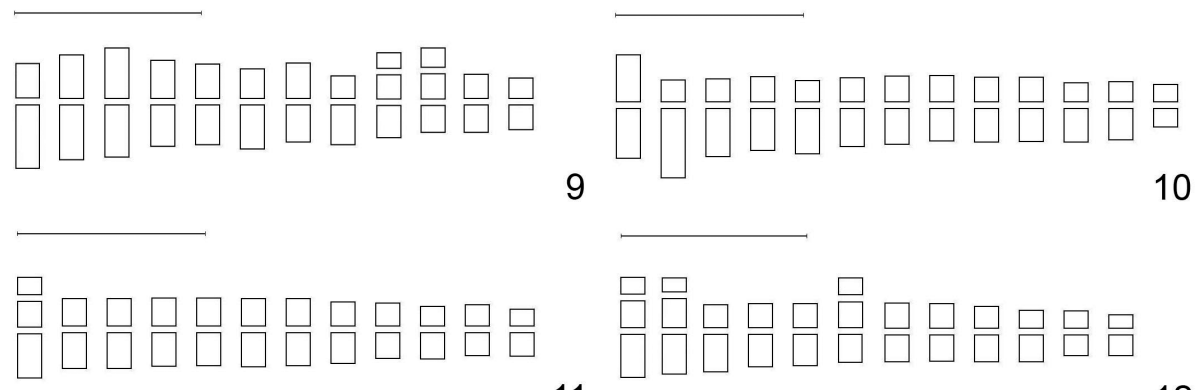

11
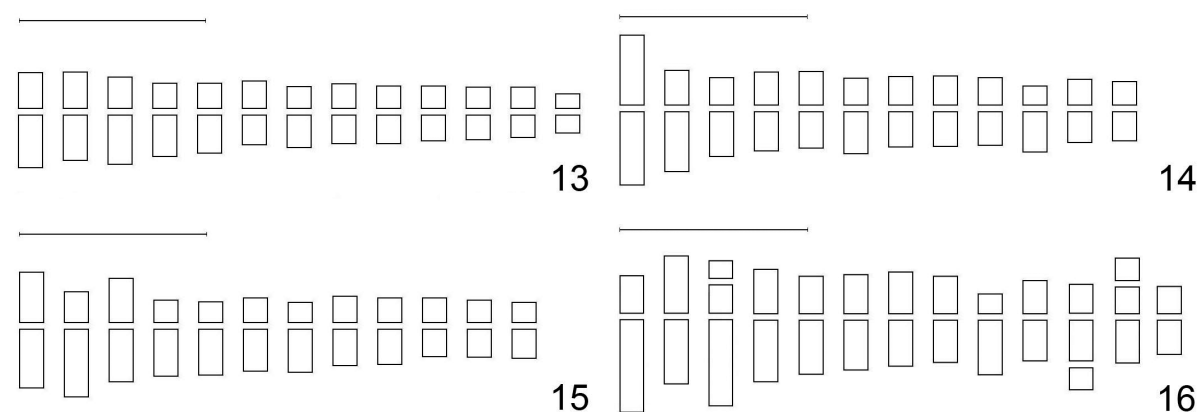

15

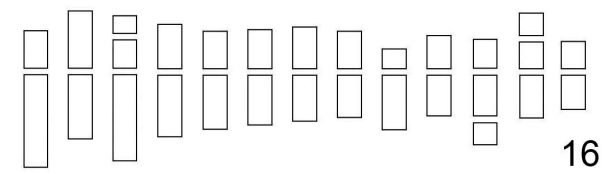

Figs. 9-16. Haploid idiograms of Cousinia species. 9. C. pulcherantha, 10. C. beauverdiana, 11. C. longifolia, 12. C. sicigera, 13. C. diezii, 14. C. lasiolepis, 15. C. haussknechtii and 16. C. cylindracea. Scale bar $=10 \mu \mathrm{m}$.

Cousinia beauverdiana Bornm.

Iran: S., NE of Kerman, Kuhpayeh, Mirtadzadini 2047, $2 n=26$ (Figs. 2 and 10).
This is the first chromosome count for this species. Among the previous reports of chromosome numbers of the species belonging to this section, only C. glandulosa 
Kult (Chukdanova, in Fedorov 1969) have shown the basic chromosome number of $x=13$. So the results of this study confirm the second number in addition to $x=12$ which has been reported previously for sect. Leiocaules (Djavadi and Attar 2010). C. beauverdiana is a narrow endemic species restricting to a small area in south east of Iran.

\section{Cousinia sect. Spinuliferae Rech.f.}

Cousinia longifolia C. Winkl. \& Bornm.

Iran: S., Bardsir, Bidkhun, Mirtadzadini 2048, $2 n=24$ (Figs. 3 and 11).

This is the first chromosome count for this species.

Cousinia sicigera C. Winkl. \& Bornm.

Iran: S., Kerman, Mirtadzadini 2049, $2 n=24$ (Figs. 4 and 12).

This is the first chromosome count for this species. Cousinia sect. Spinuliferae comprises seven species out of which five are endemic to flora of Iran (Rechinger 1972, 1979, Mirtadzadini and Attar 2004, Assadi 2009). According to the literature, chromosome number records have not been published yet for none of the Cousinia species belonging to this section. Therefore chromosome counts for $C$. longifolia and C. sicigera is the first chromosome counts for sect. Spinuliferae. Both species are distributed in center and southeastern mountains of Iran and both revealed $x=12$.

\section{Cousinia sect. Microcarpae Bunge}

Cousinia diezii Rech. $f$.

Iran: NE, Khorasan, S. of Torbat-e Heydarieh, Mirtadzadini 2050, $2 n=26$ (Figs. 5 and 13).

This is the first chromosome count for this species. Our results revealed $x=13$ for this species. Three different basic chromosome numbers of $x=11,12,13$ have been reported for sect. Microcarpae (Susanna et al. $2003 b$ ). So the number $x=13$ is consistent with the previous reports for this section. Cousinia diezii is an endemic species which is distributed in the northeast of Iran.

\section{Cousinia sect. Alpinae Bunge}

Cousinia lasiolepis Boiss.

Iran: S., NE of Kerman, Kuhpayeh, Mirtadzadini 2051, $2 n=24$ (Figs. 6 and 14).

This is the first chromosome count for this species. Two basic chromosome numbers, $x=12$ and $x=13$ have been reported for sect. Alpinae. The basic chromosome number $x=12$ has been reported for the species belonging to this section on the material originated from Central Asia; Uzbekistan and Tajikistan (according to Tscherneva 1985), Kazakhstan (Susanna et al. 2003b) and Tajikistan (López-Vinyallonga et al. 2010). For the material from the flora of Iran, only $x=13$ has been reported (Djavadi and Attar 2010). Therefore this the first report of $x=12$ for the species belonging to this section from the flora of Iran. This species is distributed in west and south parts of Iran and also in Afghanistan.

Cousinia sect. haussknechtianae Rech.f.

Cousinia haussknechtii C. Winkl.

Iran: Fars, Margun waterfall, Mirtadzadini 2052, $2 n=24$ (Figs. 7 and 15).

Cousinia sect. Haussknechtianae was described based on C. haussknechtii and C. raphiocephala (Rechinger 1972). Later C. gatchsaranica (Mehregan et al. 2003) and C. karkasensis (Mehregan et al. 2010) were added to this section. According to the literature, chromosome number records have not been published yet for Cousinia species belonging to this section. Therefore this is the first chromosome count for C. haussknechtii and this section as well indicating the basic chromosome number $x=12$. This species is distributed in west of Iran and in Iraq.

Cousinia sect. Stenocephalae Bunge

Cousinia cylindracea Boiss.

Iran: SW, Fars, Niriz, Bordbar 2053, $2 n=26$ (Figs. 8 and 16).

The basic chromosome number $x=13$ is the most frequent basic chromosome number for this section (Djavadi 2012). Cousinia cylindracea is an endemic species for the flora of Iran which is distributed in many parts of Iran. Our result for this species agrees with the previous ones by Ghaffari and Djavadi (1998) on material from Tehran, Kuh-Dashteh (north of Iran). This is an endemic species for the flora of Iran which is distributed in west and south of Iran.

\section{Discussion}

Cousinia with about 700 species is one of the largest genera of Compositae. According to the last classification of the genus, it was grouped in to three subgenera (Cynaroides, Hypacanthodes, and Cousinia) and $50 \mathrm{sec}-$ tions (Tscherneva 1988a, 1988b). All of the taxa in present study belong to Cousinia subg. Cousinia. The previous chromosome counts on Cousinia confirmed different basic chromosome number of $x=9,10,11,12$, and 13 (Susanna et al. 2003b and Ghaffari et al. 2006). According to our data, the results of this study are the first reports of the basic chromosome number within sect. Spinuliferae $(x=12)$ and sect. haussknechtianae $(x=12)$. We have also reported $x=12$ for $C$. lasiolepis from sect. Alpinae which is new for the material originating from the flora of Iran. Some sections are characterized by only one basic chromosome number, for example sect. Albidae ( $x=13$, Djavadi and Attar 2010), sect. Cousinia $(x=12$, Ghaffari et al. 2006), and sect. Helianthae ( $x=13$, Ghaffari et al. 2006). Although there are some sections with more than one basic chromosome number in the case of sect. Alpinae ( $x=12$ and 13, Susanna et al. 2003b, Tscherneva 1985, Djavadi and Attar 2010, and present 
study), sect. Pugioniferae ( $x=12,13$ and 14, Aryavand 1975, Djavadi and Attar 2010, and present study), sect. Microcarpae ( $x=11,12$ and 13, Susanna et al. 2003b, Tscherneva 1985, and present study), and sect. Leiocaules ( $x=12$ and 13, Djavadi and Attar 2010, Fedorov 1969 , and present study). The result of this study confirmed the basic chromosome number of $x=13$ for sect. Leiocaules which has been reported previously by $\mathrm{Fe}-$ dorov (1969) for C. glandulosa but it was supposed to be erroneous by Djavadi and Attar (2010).

Like other groups of tribe Cardueae it has been accepted for Cousinia that the basic chromosome numbers indicate a descending dysploid series of $x=13$ to $x=9$ which means that higher basic chromosome numbers should be considered as more primitive than the lower ones. It has been argued that descending dysploidy might be related to arid habitat of Cousinia species (Susanna et al. 2003b, López-Vinyallonga et al. 2010).

Up to now there is no evidence of polyploidy or hybridization within Arctium-Cousinia complex. It has been suggested that if hybridization is present, it may occur rarely or occur between species with the same chromosome number resulting in homoploid hybridization (López-Vinyallonga et al. 2010).

\section{Acknowledgement}

This study was supported by Shahid Bahonar University of Kerman.

\section{References}

Agayev, Y. M. 1996. Advanced Squash Methods for Investigation of Plant Chromosomes. In: The Fourth Iranian Congress on Crop Production and Breeding Sciences. Isfahan University of Technology, Isfahan. pp. 1-20.

Aryavand, A. 1975. Contribution to the cytotaxonomic study of some angiosperms from Iran. Bot. Not. 128: 299-311.

Assadi, M. 2009. Four new species of the genus Cousinia Cass. (Asteraceae) from Iran. Iran. J. Bot. 15: 36-44.

Djavadi, S. B. 2007. New or rare Chromosome counts in ten species of Cousinia from Iran-II. Rostaniha 8: 19-27.

Djavadi, S. B. 2012. New chromosome counts in Cousinia (Asteraceae, Cardueae) sections Cynaroideae and Stenocephalae from Iran. Iran. J. Bot. 18: 86-93.

Djavadi, S. B. and Attar, F. 2010. New chromosome counts in the genus Cousinia (Asteraceae, Cardueae) from Iran. Willdenowia 40: $351-357$.

Fedorov, A. A. 1969. Chromosome Numbers of Flowering Plants. Academy of Sciences of the USSR, Leningrad.

Ghaffari, S. M. and Djavadi, S. B. 1998. Chromosome studies and dis- tribution of nine species of Cousinia section Stenocephalae (Asteraceae) in Iran. Bull. Soc. Neuchateloise Sci. Nat. 121: 61-68.

Ghaffari, S. M., Garcia-Jacas, N. and Susanna, A. 2006. New chromosome counts in the genus Cousinia (Asteraceae) from Iran. Bot. J. Linn. Soc. 151: 411-419.

López-Vinyallonga, S., Susanna, A. and Garcia-Jacas, N. 2010. Chromosome Numbers in the Genera Cousinia, Olgaea and Syreitschikovia (Compositae). Folia Geobot. 45: 201-214.

Mehregan, I., Assadi, M. and Attar, F. 2003. Cousinia (sect. Haussknechtianae) gatchsaranica, a new species from SW Iran. Willdenowia 33: 107-111.

Mehregan, I., Djavadi, S. B. and Pahlevani, A. H. 2010. Cousinia (sect. Haussknechtianae) karkasensis, a new species from Karkas Mts. in central Iran. Iran. J. Bot. 16: 200-203.

Mirtadzadini, M. and Attar, F. 2004. Cousinia (sect. Spinuliferae) hazarensis (Compositae, Cardueae), a new species from SE Iran. Willdenowia 34: 191-194.

Mirzaghaderi, G. and Marzangi, K. 2015. IdeoKar: An ideogram constructing and karyotype analyzing software. Caryologia $\mathbf{6 8}$ : $31-35$.

Parishani, M. R., Rahiminejad, M. R., Mirtadzadini, M. and Saeidi, H. 2014. New chromosome counts of six taxa of Cardueae (Asteraceae) in Iran. Iran. J. Bot. 20: 29-35.

Rechinger, K. H. 1972. Flora Iranica, Vol. 90: Compositae-Cynareae I: Cousinia. Akademische Druck- und Verlagsanstalt, Graz.

Rechinger, K. H. 1979. Flora Iranica, Vol. 139a: Compositae-Cynareae III: Cousinia. Akademische Druck- und Verlagsanstalt, Graz.

Rechinger, K. H. 1986. Cousinia: Morphology, taxonomy, distribution and phytogeographical implications. Proc. R. Soc. Edinb. Biol. Sci. 89: 45-58.

Sheidai, M., Ahmad-Khanbeygi, Z. and Attar, F. 2012. New chromosome number reports in Cousinia Species (Compositae). Cytologia 77: 11-16.

Soltis, D. E. 2014. Chromosome data. Iran. J. Bot. 20: 228-229.

Susanna, A. and Garcia-Jacas, N. 2009. Cardueae. In: Funk, V. A., Susanna, A., Stuessy, T. F. and Bayer, R. J. (eds). Systematics, evolution, and biogeography of Compositae. International Association for Plant Taxonomy, Vienna. pp. 293-313.

Susanna, A., Garcia-Jacas, N., Vilatersana, R. and Garnatje, T. 2003 a. Generic boundaries and evolution of characters in the Arctium group: A nuclear and chloroplast DNA analysis. Collect. Bot. 26: 101-118.

Susanna, A., Garcia-Jacas, N., Vilatersana, R., Garnatje, T., Vallès, J. and Ghaffari, S. M. 2003b. New chromosome counts in the genus Cousinia and the related genus Schmalhausenia (Asteraceae, Cardueae). Bot. J. Linn. Soc. 143: 411-418.

Tscherneva, O. V. 1985. Chromosome numbers in the species of the genus Cousinia (Asteraceae) in the flora of the USSR. Bot. Zhurn. 70: 856-857. (in Russian)

Tscherneva, O. V. 1988a. A synopsis of the Cousinia (Asteraceae) genus system in the flora of the USSR. Bot. Zhurn. 73: 870-876. (in Russian)

Tscherneva, O. V. 1988b. The Cousinia of the SSSR. Akademiya Nauk SSSR, Leningrad. (in Russian)

Zare, M., Khosravi, A. R. and Joharchi, M. R. 2013. Distribution patterns of the genus Cousinia (Asteraceae). Iran. Iran. J. Bot. 19: $127-141$. 